Journal of Business Management and
Economic Research
2018, 2(12): 26-36 DOI: 10.29226/TR1001.2019.95
Journal Homepage: https://www.jobmer.org

\title{
Socio-Cultural Impact of illegitimate Land Sale or Land Grabbing in Community, in Dire Dawa City of Ethiopia
}

\author{
Shambel Tufa Telila \\ Assistant Professor in Social Anthropology, Lecturer at Dire Dawa University \\ Dire Dawa, Ethiopia, shambeltufa@yahoo.com, shambelt614@gmail.com
}

\begin{abstract}
This study has investigated "Socio-Cultural Impact of Land Sale or Grabbing on Community in Dire Dawa City" which tried to show the impact of illegal land sale and land gabbing on cultural influence, food insecurity, water insecurity, less development of infrastructure and environmental degradation.

Therefore, the researcher used instruments of data collection both primary and secondary methods. The primary data are collected from the field through Interview, Focus Group Discussion and Researcher Field Observation. In interview about 100 street vendors' informants were involved and in FGD about 40 discussants in six groups were involved the secondary sources are obtained from written sources.

Consequently, qualitative method of data analysis was used by the researcher to analyze the collected data's through the above mentioned instruments of data collection. The data from interviews, focus group discussion and field observation were transcribed, and triangulated with secondary sources.

The study further investigated the effect of cultural violation by the new arrivals create problems and social relationships, and violated land owning right which tend to influence their food and water insecurity. The government officials contribute to less development and environmental degradation. Generally, it is unlikely that social problems can be resolved by in dealing with such informal activities among these local communities and analyzing the societal and individuals ties in particular and the whole community had been broken in wide-ranging. The implications of the outcomes of the study is that in providing recognition and to create the awareness how local communities have to solve problems with the government and the new comers to their local areas formally and informally,. Thus, it is crucial to conduct further studies in a broader scope to advance into the significance of social problems for poor targeted development interference in Dire Dawa.
\end{abstract}

Keywords: Social, Cultural, Impact, Illegitimate Land Sale or Land Grabbing, the Community 


\section{Background of the Study}

The most common definition of the global land grab refers to large scale land acquisitions by foreign investors either through purchase or lease for agricultural production (Cotula, Vermeulen, \& Keeley, 2009). Land grabbing refers to land acquisitions by transnational corporations, business enterprises, private investors, and foreign governments through sale or lease contracts - some of which are for up to 99 years - which are highly detrimental to the interests of local communities. Highly productive land and access to water are acquired by investors usually for the production of food crops most of which are for export (including genetically modified organisms which continue to be at the centre of fierce international debate owing to health and environmental concerns), bio-fuels, and extraction of raw minerals. The deals are frequently reached without including at all in the process of consultations and negotiations the local communities living on the land being sold or leased. In many cases host communities, and even host governments are NOT compensated appropriately for the actual value of the land. In numerous instances the local communities have NOT given their free, prior and informed consent to the purchase or lease of land, on which in many cases they have lived for centuries (Liversage, 2010).

As a result, in many parts of the world land grabbing is already leading to social conflicts, massive internal displacement of people as well as loss of their cultural identity, systematic human rights violations, destruction of livelihoods, poverty, permanent environmental damage, pollution and loss of biodiversity. Indigenous people's leaders, community leaders and human rights defenders who speak out on behalf of their communities affected by land grabs are frequently persecuted, are victims of torture, arbitrary detentions, enforced disappearances and assassinations (Borras, Kay, Gómez, Wilkinson, 2012). The key issue is now whether the prospects for food security and poverty reduction in developing countries, and globally in general, are better with or without agriculture investments, and what are the best ways to maximize benefits and avoid negative effects on agriculture investments in sub-Sahara countries. For a continent that is quite used to being exploited, small-scale farmers have to be a priority, as well as protecting Africa and making sure the continent benefits equally from global investors. Otherwise, farmers of developing country will be the first victims of the present rush for land. According to various reports, it indicates that in less than a year, foreign investors and companies acquired around 56 million hectares of land globally (Deininger \& Byerlee, 2011). Of these, above half of them (29 million ha.) were in sub-Saharan Africa countries (Lehavi, 2015).

World Development Movement (WDM) published a report also in April 2014 titled "Carving up Continent". It underlines that the multinational corporations take over African food systems and farming lands. According to the report, multinational companies have signed agreements with a number of African countries to establish agriculture investment under the aspect of fighting poverty and food insecurity (Mwesigire, 2014).

\section{Unlawful Land Grab in Ethiopia}

The Ethiopian government and international bodies such as the World Bank have presented the commercialization of land and the shift to large scale agriculture as being an essential measure 
for agricultural modernization and to the improvement of production efficiency which will lead to increased food production and economic growth (World Bank, 2007). According to the World Bank's argument, population growth in the developing countries like Ethiopia will lead to increased demand for food products, expanding urbanization, and rising incomes which needs to be met by bringing more land into farming and by improving productivity. Like many scholars worldwide, the WB's conclusion is that Africa will benefit greatly as it has plentiful potential farmland and by closing the productivity gap on the ones under cultivation. Supporting the WB's argument the Ethiopian government also confirms that there is plenty of "unused" land for investors to operate efficiently without posing a threat to the livelihood of smallholders.

Ethiopia is an important case in the international debate on large-scale land acquisitions (WFP \& CSA, 2014). It challenges assumptions about foreign dominance of land investment, or that large-scale land deals are primarily for food crops for export (Rahmato, 2011). It is a case where land deals for plantation agriculture are central to government agricultural strategy, but also where allocations have been subject to controversy in terms of impacts on rights and livelihoods at the local level (Keeley, Seide, Eid, \& Kidewa, 2014). Land deals promise to contribute to improved food security, through the generation of foreign exchange; improved incomes as a result of on- and off-farm employment created by investment projects; and food production that is marketed within Ethiopia (FAO, IFAD and WFP. 2015). If people directly lose their land without compensation or adequate resettlement, including access to productive resources, however, they will likely be worse off and more food insecure. Where there is a loss of access to resources that are important parts of livelihood systems and coping mechanisms, such as forests, rangelands, and water resources, there are clear risks of pockets of greater food insecurity at the local level (Damtie, \& Bayou, 2008).

These local-level impacts are not currently well documented for Ethiopia, partly due to the political sensitivities of carrying out this kind of research in many key land investment areas (Liu, 2014). Land deals in Ethiopia promise to create significant amounts of employment. Lack of presentation means that job creation has not lived up to expectations, however, although this may change if investments are fully operationalized. For a limited number of investments, substantial numbers of jobs have been created (Oakland Institute, 2011). In developing regions, these are often taken by workers from outside the regions, rather than ethnic groups from within the region. This has contributed to conflict in some instances, and needs to be better addressed through quotas and training programmers. The cultural difference between a pastoralist lifestyle and wage labor employment on a plantation should not be underestimated, however; the change in identity required may well be resisted by many pastoralists. As with other aspects of land deals, creation of clear baseline information, in this case on employment and livelihoods in targeted areas, would allow for monitoring of performance over time (Geary, 2012). 


\section{Methodology}

\subsection{Research Design}

This study was designed to focuses on the Socio-cultural impact of illegal land sale and land grabbing in Dire Dawa city which leads to strive for daily food and with communities who are with no additional income and those with little income.

The rationale for the selection of the area and the topic was that there is more importantly abundance of land grabbing in the area and around the city by the government officials and by the community itself, who are living around in Dire Dawa city engaged in different types of business. Communities in and around city of Dire Dawa engaged in this activities as means of escaping from poverty, as means of survival and some others used as additional income. This has to be comprehensive enough, to look into the lives of these communalities that enables the researcher to show the magnitude and heavy link between illegal land sale as means of survival, and that brought social and cultural impact on their life which are exceptionally strike these group of people in identifying contradictory behaviors, beliefs, attitudes, emotions and relationships of individual. Therefore, this research was based on the illegal land sale by community and land grabbing by government officials in Dire Dawa city. The researcher was used supplement the information's from books, bulletins, and different articles written in addition to gathered data's from field.

\subsection{Data of Source}

Both Primary and secondary source of data were used by the researcher. The primary sources were obtained from the field through Interview, Focus Group Discussion and Field Observation by the researcher. Secondary sources of data were data obtained from published and unpublished sources. These secondary sources of data were used to relate and triangulate the research problem of their past with situations on real ground which was obtained from primary sources of data, that were obtained from the field (Wolcott, 2009).

\subsection{Type of Data}

Primary and secondary types of data were used to understand this paper. The primary data's were the data's collected from field through different techniques of data collection such as interview, focus group discussion and field observation. The data obtained from interview, focus group discussion and from field observation were triangulated in line with the importance of the sources as discussed in review literature earlier. Thus, primary data's were collected from the field and through direct observations while secondary data types were also used from different written sources.

\subsection{Instrument of Data Collection}

Three types of primary data collections apparatus were used to collect the relevant, appropriate and reliable primary data from the field. These include interview, focus group discussion and 
field observation, and which are very important to explore the issue under study (Leedy, and Ormrod, 2009).

In Interview about 100 informants, in focus group discussion about 40 discussants were participated and field observation was used to get the first hand information from the field to fulfill the gap identified by the researcher. Secondary sources were also used to strengthen the validly of paper. Therefore, the researcher employed different these three types of tools or instruments to collect the most reliable data that are necessary to strengthen the reliability of the outcome of the study (Finke, (2010).

\subsection{Method of Data Analysis}

Qualitative method data analysis was used to make the research influential and significant for the sake understanding the issue under discussion (Richie, and Lewis, 2003, Byrne, 2002). The researcher tried to look into the view of informants and discussants to investigate the issue of social and cultural impact of illegal land sale and their livelihood and challenges they meet in nowadays and future. One occasion important for the researcher is that data collected from the field were qualitative which were collected from the field through personal observation, interview and focus discussion (Flick, (2009). The researcher also used secondary data sources to strengthen the ideas obtained from qualitative data. The researcher used various information to complete and triangulate the collected data to increase and strengthen the validly and reliability of the outcome the research.

\section{Ethical Consideration}

Anthropologist key question to investigate the problems of societies under study, they have to have permission, and they must have to consider the permission of the host community about the research whether the research had a risks to these group of people (Mathers, Nigel; Howe, Amanda; and Hunn Amanda, 1998). The researcher has the responsibility to avoid the risks that these societies will face due to this study; the society have to continue their everyday activities without interruption of the researcher work in to their social and economic affairs to investigate the issue under examination. That is why every Anthropologists need to have permission to study societies at their original setting in search of solution for problems that the societies have faced or bring negative impact to the communities under study (Mauthner, (ed.), (2002). Everything about the society under study would be kept in secret or not exposed without the consent of the host societies.

Therefore, the researcher had confirmed these Street vender Women's about this study in which the investigation did not affect any body negatively either communities in focus or the others who were in methods for realization of this paper. The researcher gave much attention for dignity, respect, privacy life and democratic thinking, for people under study and for the informants and discussants in data collection. 


\section{Finding And Discussion}

\subsection{Perspectives of Land Grabbing}

\subsubsection{The Social Situation of Land Grabbing in Area}

The main access to land and who have land right is the local community in and around the city who have the social and economic institution there. The situation on land sale in area was involved by the community who are residing in and around the city itself. It was the source of food insecurity in the area and as the same times the sources of conflict over the right of the land. The community who engaged in illegal selling of land was in conflict with neighbors and with their own relatives' brother father and so on. Even those with the right of entry to public information are illegal land sellers or land grabbers who were largely restricted to some parts of society who claimed that as if they were original residents. These communities sell land illegally for those communities who are out of their original community who reside for the sake of having shelter. The illegal buyers are composed of different communities of different ethnic groups. This brought social situation more concentrated between these different ethnic groups.

There the researcher observed that the social circumstance in the land grabbing area is not good for the reason that both communities are not in a good condition to interact to each other. This was intensified by the political condition in the region now.

\subsubsection{The Political situation of Land Grabbing}

Ethnically the late comers or those who bought land illegally brought every movement as politically designed to provide livelihood to these different ethnic groups. Illegal land selling by the original community and land grabbing by the government officials brought tension between the two communities and becoming place of turmoil. The issue of political situation in the area is always in tension and government police forces are deployed for the security reason in the area. The irregularities of observation by the government official's was intentional not look what is going on the ground to open dissent towards the government and its policies is not tolerated. For those who oppose the government, harassment, detentions, and imprisonment are common practices in today of societies who are on land sale or land grabbing in Dire Dawa and as a result, there is a widespread fear of culture with regard to opposing the government.

\subsubsection{The Economic Circumstance of illegal Land sale or Grabbing}

The local communities' displacement of as a result of illegal land sell and land grabbing deals clearly has a disadvantageous effect on their ability to source food and water as well as housing with consequential impacts on health and wellbeing. Without making alternative arrangements for local community members of those communities to who grow on their parents land have less accesses to food and water. The accesses to land have as a means of survival is common for the societies who reside around the city. But such displacement should have to be considered a violation of the rights on land ownership for the local and original communities. But the problem was they themselves who sale land on illegal way for the new comers or the residents of city. Questionably, these communities sale their land for two reasons, one for the economic 
reason and on the other hand for reason of land rights that government sale their land without enough compensation to their land.

Thus, the practices by the government officials have negatively impact on original land owners make to have neighboring landholders. Moreover, the long-term effect of land grabbing and destructive way of snatching land practices from the local communities had diverse effect on the environment will affect the ability of future generations to feed and house themselves with the potential for violation of their right to an adequate standard of living. The principles of sustainable use, equity and the protection of rights under the Ethiopian government Constitution are thus mutually reinforcing. The government work to ensure sustainable use of natural resources is also reflected in the protection provided for the land rights of indigenous peoples to the natural resources in their lands. Displacement of indigenous communities of the kind taking place in Ethiopia, especially forced removal of communities, in our view, is a clear violation of the rights of these communities protected by international law.

\subsection{The Impact of Illegal Land Sale and Land Grabbing}

\subsubsection{Leads to Loss of Culture}

Illegal land sale by the local communities and land grabbing by government officials brought impact on the cultural practices local communities who owned the land previously. The new comers brought new cultural composition in the area resides by original communities before. One of my informants expresses the situation like this:-

We know our culture before our land was occupied by the new comers. Many new cultural practices are happened nowadays in our locality. We tend to forget our cultural practices and its significance. For instance there was annual celebration of festivals, but today many annual celebrations are celebrated. Our land was reduced and we become urban dwellers totally and we were treated as if we were urban dwellers, and there is no social status between elders and younkers.

Several local communities were affected by illegal land sale and land grabbing culturally and land is closely bounce with cultural identity and associated to a variety of cultural practices. Some land areas are considered as the spiritual significance areas by local communities, and some parts of land are considered as sources of foods, where food was collected from particular areas that have a fertile background. The researcher observes:

In area of Sost killo about five kilometers away from the city, the area is more fertile with small and scanty rainfall and grown Sorghum which was sources of livelihood for the local communities. But now a days this fertile land was sold for city residents, which brought problem on food consumption for local societies. 
The long-established and spiritual ceremonies of communities depend up on plants and trees tend to decrease. For indigenous communities, the loss of inherited land strikes at the core of their very identity, harmfully affecting their way of life.

\subsubsection{Loss of Insecurity of Land rights}

Local communities land use and ownership of land which was governed by communal land holding systems with local communities rarely having formal land possession rights. Formal ownership of land, especially in surrounding rural areas of the city is often belongs to society who claimed that it was their ancestral land.

But individuals had access to land through local customary possession systems which have the right to share their ancestor land, and benefit from it only weak legal protection in accordance of government law and constitution. This leaves local communities to loss their legal proprietary rights vulnerable against government officials land grabbing and illegal selling of land by themselves to protect their land snatched by the others.

This is the situation in Dire Dawa and around the city was directly involved by the local community and officials who share local land in the name of the protection of law. Local community customary land rights are protected by "law", this is because government officers were involved by means of legal protection. Indeed, land grabbing may likely make worse urban poverty in the city that are already stressed and result in a net transfer of wealth from the poor to the rich. The next part examines the relationship between land grabbing and principles of sustainable development in international law.

Illegal land selling and land grabbing has provoked a great deal of debate between local community or land owners and government officials who demand for land to be purchased by the name of legal protection. The local communities who claimed their land was often passed to these generation from their ancestors, feel more insecurity of their land. According to them their land was snatched by government formal and legal protection of law and by the name of investment. One of my informants described the situation like this:-

Government officials are always on quarrel with us on our ancestor land. The issue is not for the sake government investment, but for the sake they. We feel unsecured because of our land, and sometimes fight with them for our own right.

The insecurity on land ownership consider various impacts of land grabbing on local populations affected by transnational land getting hold of can benefit from the land itself. It is dynamically debated whether land contract actually benefit local communities and whether the interests of communities are protected when such transactions are formed or to the government officials who sale land under the umbrella of legal protection. A study of land acquisition contracts has completed that land renewal requirements are not generally included.

\subsubsection{Leads to Water insecurity}

Illegal sale of land by local communities land grabbing by the government officials has significant implications for water insecurity due to the reliance on the availability of fresh water for drinking and small scale farming around the city. One of the principal considerations for land grabbers are the acquiring land is often is the looting of their personal ownership on land. Therefore, access to water resources, is unsecured due to the increased interest in water by the new comers which has also driven by the impact of climate change, with rising temperatures and more frequent droughts likely to intensify the need for more water supply to the residents. Matrimonial practices occur in relation to water insecurity on the land sold land or grabbed land disagreements will happen due to the scarcity of the availability of fresh water to drink. 
There is little or no contemplation of the unfavorable impact of increased water taking out and no stated limitation on the use of water.

Unregulated water use may further lead to overuse of water by the new comers or the people who purchase land for construction. The implications for water insecurity are similarly the concern of the government and the city administration. This issue may lead the society to a conflict over water share.

\subsubsection{Less Employment and Infrastructure}

The employment caused in the area of illegal land selling communities and government officials grabbing of land, was sever to the local communities. Their land is often promoted as providing opportunities for employment to revitalize the benefit of local communities by providing food security and reliance on the skills development, and access to technology and connection to global markets. Employment is largely considered by the local community as widely seen to be necessary to bring more development of their area into production and to provide local employment opportunities. Local communities assumed that governments and government officials on the basis that land leases and grabbing were to provide them with the necessary resources to buy food on the global market. The questionable is that for the benefit local communities who owned the land, or for the benefit of government officials who sold the land under legal protection. The case of infrastructure development is also give emphasis to an advantage of local communities in the area. On the other hand, whether and how land sale can benefit local communities depends to a large extent on their design and management. Less development of infrastructure leads the community to quarrel with the government. It brought tension between the government and the local communities.

\subsubsection{Leads to ecological damage}

Ecological damage resulting from illegal land sale by the community and land grabbing by the government officials was the practices includes destruction of soil fertility, pollution of water sources, loss of biodiversity and draining of everglade. Illegal land sale and land grabbing is a series effect on the local environment, such as indigenous trees, and some bushes in the area.

The changes the natural ecosystem affects biodiversity in areas and has a diverse effect on local communities. The absence of tree plantations has led to soil erosion and flooding in surrounding land. An environmental dreadful condition forces local communities and some urban dwellers to leave their native lands. Some relocate to cities, while others clear bushes for construction or peat land to continue home building, thus perpetuating the cycle of environmental destruction.

\subsubsection{Leads to food insecurity}

The final demand of illegal land selling and land grabbing demonstrates that land grabbing often involves the relocation of local communities in order to clear land for purchase. New comers are usually more interested in having home constructed than addressing local unemployment or food insecurity. They favor flat and suitable areas for construction of beautiful homes, which are not exposed for erosion sometimes. Until now, many of the areas leased to the new comers who can purchase from the government formally and others are vulnerable to drought, flooding, and conflict.

This condition leads the local communities and even the new comers to food insecurity who have no other options to do rather than waiting for what happing than doing something better. Food insecurity is common in around the city of Dire Dawa, due to the existence of the city in harsh environment. Dire Dawa is the hottest city where edible fruits and cereals are not grown 
except for sorghum crop. Land sale has reduced access to water sources and degraded water supplies as a result of water erosion, in many cases where communities have been relocated to accommodate officials; and the replacement in money land has been made available to local communities in insufficient way.

\section{Conclusion}

Land grabbing is a fast growing trend in the developing countries like Ethiopia, which has gained momentum particularly in these countries as government access to land. The illegal selling by the local communities and grabbing by the government officers is not limited to tillable land; it goes further to capture urban lands and it's surrounding. Land reserves in urban and rural areas are purchased by the name of investment to riches. The sale of land started when the legal legislation permitting the government sale the land buy land every-where in every pockets of the country urban-rural areas. Other factors came to deepen the structural, institutional, cultural, historic, legal, and economic, reason that the government began to sale the land under the coverage of legal protection.

These conditions lead the local society or communities to several local communities were affected by illegal land sale and land grabbing culturally and land is closely bounce with cultural identity and associated to a variety of cultural practices. Some land areas are considered as the spiritual significance areas by local communities, and some parts of land are considered as sources of foods, where food was collected from particular areas that have a fertile background.

Local community customary land rights are protected by "law", this is because government officers were involved by means of legal protection. Indeed, land grabbing may likely make worse urban poverty in the city that are already stressed and result in a net transfer of wealth from the poor to the rich. Unregulated water use may further lead to overuse of water by the new comers or the people who purchase land for construction. The implications for water insecurity are similarly the concern of the government and the city administration. Less development of infrastructure leads the community to quarrel with the government. It brought tension between the government and the local communities. The absence of tree plantations has led to soil erosion and flooding in surrounding land. An environmental dreadful condition forces local communities and some urban dwellers to leave their native lands. Food insecurity is common in around the city of Dire Dawa, due to the existence of the city in harsh environment. Dire Dawa is the hottest city where edible fruits and cereals are not grown except for sorghum crop.

\section{References}

Borras, Kay, Gómez, Wilkinson, (2012). Land grabbing and global capitalist accumulation: key features in Latin America. pp 402-416

Byrne (2002) Interpreting Quantitative Data. London: Sage

Cochrane, (2011). Food security or food sovereignty: The case of land grabs. The Journal of Humanitarian Assistance, Tufts University, Feinstein International Center.

Cotula, (2011). Land grab or development opportunity? International farmland deals in Africa. Bogotá: Colombia FDI Perspectives. 
Cotula, Vermeulen, Leonard, \& Keeley, (2009). Land grab or development opportunity? Agricultural investment and international land deals in Africa. London and Rome.

Damtie, \& Bayou, (2008). Overview of environmental impact assessment in Ethiopia: Gaps and challenges. Addis Ababa, Ethiopia: MELCA Mahiber.

Deininger, \& Byerlee, (2011). Rising global interest in farmland: Can it yield sustainable and equitable benefits? Washington, D.C.: The World Bank Publications.

FAO, IFAD and WFP. (2015). The state of food insecurity in the world 2015. Meeting the 2015 international hunger targets: Taking stock of uneven progress. Rome: FAO.

Finke, (2010). Conducting Research Literature Reviews: From the Internet to Paper (3rd Flick, U. (2009). An Introduction to Qualitative Research (4 $4^{\text {th }}$ edition). London: Sage.

Flick, (2009). An Introduction to Qualitative Research (4th edition). London: Sage.

Geary, (2012). Our land, our lives: Time out on the global land rush. Oxfam Policy and Practice: Private Sector, 9(2), 1-26.

Keeley, Seide, Eid, \&Kidewa, (2014). Large-Scale land deals in Ethiopia: Scale, trends, features and outcomes to date. London: IIED.

Lehavi, (2015). Land law in the age of globalization and land grabbing. In M. Graziadei and L. Smith (Eds.), Comparative property law: Global perspectives. Edward Elgar Publishing.

Liu, (2014). Impacts of foreign agricultural investment on developing countries: Evidence from case studies. FAO Commodity and Trade Policy Research Working Papers, Rome.

Liversage, (2010). Responding to "land grabbing" and promoting responsible investment in agriculture. IFAD Occasional Paper

Leedy, and Ormrod, (2009) Practical Research: Planning and Design (9th edition). Harlow: Pearson.

Mathers, Nigel; Howe, Amanda; and Hunn Amanda (1998). Trent focuses for research and development in primary health care. Ethical considerations in research. Trent focus,

Mauthner, (ed.) (2002) Ethics in Qualitative Research. London: Sage.

Mwesigire, (2014). Land grabbing in Africa, the new colonialism.

Oakland Institute. (2011). Understanding land investment deals in Africa.

Rahmato, (2011). Land to investors: Large-Scale land transfers in Ethiopia. Addis Ababa, Ethiopia: Forum for Social Studies.

Richie, and Lewis, (2003) Qualitative Research Practice: A Guide for Social Science Students and Researchers. London: Sage.

The World Bank. (2007). World development report 2008: Agriculture for development. Washington, D.C.

WFP \& CSA (2014). Comprehensive Food Security and Vulnerability Analysis (CFSVA). Addis Ababa, Ethiopia: Central Statistical Agency (CSA) \& World Food Programme (WFP).

Wolcott, H. (2009). Writing up Qualitative Research (3rd edition). London: Sage. 